\title{
Effect of 1-MCP and chemicals on the vase life of Rosa hybrida L. cv. 'Bordeaux'
}

\author{
Feigel-Terék, O. ${ }^{1}$, Jámbor-Benczúr, E. ${ }^{1}$, Mosonyi, I. $^{1}$ \& Máthé, Á. ${ }^{2}$ \\ ${ }^{1}$ Corvinus University of Budapest, Faculty of Horticultural Science Department of Floriculture and Dendrology \\ ${ }^{2}$ West-Hungarian University, Faculty of Agriculture and Food Science, Department of Botany, \\ Mosonmagyaróvár, Hungary
}

Summary: The effect of 1-MCP on rose cultivar 'Bordeaux' was studied in combination with different preservative solutions. The flowers were treated with 1-MCP for 6 hours at $17{ }^{\circ} \mathrm{C}$ and for 18 hours at $4{ }^{\circ} \mathrm{C}$. As for the diameter of flowers the best results was achieved, when applying $20 \mathrm{gL}^{-1}$ sucrose + Clorox $\left(2 \mathrm{mLL}^{-1}\right)$, as well as preservative "Spring" $\left(10 \mathrm{gL}^{-1}\right)+1$-MCP $(18$ hours $)$. Similar results were measured in the case of Spring + Clorox $+20 \mathrm{gL}^{-1}$ sucrose with 1-MCP ( 6 and 18 hours). The longer MCP treatment gave better results as compared to the shorter ones, because the flowers were much more open. The condition of flowers was the best in the solution of Clorox $+20 \mathrm{gL}^{-1}$ sucrose and Spring solution combined with the longer MCP treatment, and Clorox $+20 \mathrm{gL}^{-1}$, on the $10^{\text {th }}$ day. The longest vase life (10,3 day) was observed in the case of Spring application combined with 18 hours of MCP treatment. In this treatment the vase life was prolonged by 3,3 days. As regards the calculated ornamental values, the following sequence could be established: "Spring" + 1-MCP (18hrs) 134 points, Clorox $+20 \mathrm{gL}^{-1}$ sucrose $+1-\mathrm{MCP}(18 \mathrm{~h})$ with 129 point, and the third was the Clorox $+20 \mathrm{gL}^{-1}$ sucrose with 119 point.

Key words: chlorophyll, Clorox, sucrose, flowers diameter, 1 -MCP, ornamental value.

\section{Introduction}

The roses are the most significant cut flowers all over the world. Todate, the production centres for cut flowers has separated from the consumption areas (Tshwenyane \& Bishop, 2009). This hold also true of roses, where production has concentrated typically to areas with suitable climate and relatively cheap workforce. Consequently, the major part of cut roses is imported. Roses will normally reach the end consumer within 4-6 days with the distribution chain not always being smooth (Pizano, 2009). Because of this, it is important to preserve the post harvest value of cut roses also during transport.

The postharvest performance of cut flowers depends on various factors (Ichimura et al., 2002; Mayak et al., 1974). It is influenced by genetic factors, growing conditions and flower handling (Pizano, 2009). Nell (2005) have demonstrated that the influence of transport temperature on the quality of the cut roses. According to Tshwenyane and Bishop (2009), the harvesting time is fundamental factor, since it has a decisive effect on the final quality of the flowers.

The greatest effect on cut flowers is caused by ethylene. Many researchers have justified favourable effect of 1-MCP's [Sisler Serek (1997, 1999, and 2001), Hassan Gerzson (2002), Hassan \& Schmidt (2003)]. Hassan et al. (2004) studied the effect of different concentrations of 1 -MCP on various rose cultivars. According to him, the 6 hour treatment, in a concentration of $0,5 \mathrm{gm}^{-3}$ has proved to be the most effective in prolonging the vase life. Cuquel et al. (2007) found that the treatment of 18 hours was better then the 6 hours. The two cultivars studied differed from each other both from the point of 1-MCP concentration $\left(0,25 \mathrm{gm}^{-3}\right.$, and $0,5 \mathrm{gm}^{-3}$ ). Nell justified in their experiments, that the 1 -MCP treatment prevented petal shatter and ensured a longer vase life for cut roses (Pizano, 2009).

T. Windish \& Richter (2008) studied the effect of 5 different commonly used preservatives on the cultivars 'Passion' and 'Royal Sensation' originating form Dutch and Hungarian growers, respectively. The application of the preservatives "Spring" and "Liquid Rose Food" gave the best results in the case both of rose cultivars. It was found that, the vase life was 12 and 15 days for the roses originating from Holland and Hungary, respectively.

In our experiments we aimed at ensuring the longest possible vase life for cut roses. Our farther aim was to study the effect of 1-MCP applications of different duration, also in combination with the preservative 'Spring', sucrose (SU) and the detergent "Clorox" (CL).

\section{Materials and methods}

In the experiments the Rosa hybrida L. cv. BORDEAUX with large red flowers was used. The flowers were obtained directly from a grower, in Hungary. Each treatments had 3 replicates with 10 flowers each. Distilled water was used as control solution and it was also used to dissolve the 
chemicals. "Spring" was used due to its widespread use in the floral industry for prolonging the vase life of cut flowers.

1-MCP was purchased in the form of powder that upon addition of water yielded a colourless and odourless gas, an antagonist to ethylene. Flowers were treated with 1-MCP for 6 hours at $17{ }^{\circ} \mathrm{C}$ (Hassan et al. 2004), and for 18 hours at $4{ }^{\circ} \mathrm{C}$, at a concentration of $0.5 \mathrm{gm}^{-3}$. Subsequently, the stem of flowers was cut back to $50 \mathrm{~cm}$ and the lower leaves were removed.

The experiments were carried out in the laboratory of the Department of Floriculture and Dendrology, Faculty of Horticultural Sciences, Corvinus University of Budapest. Start of experiments: 29. June 2009. Frequency of evaluations: every $3^{\text {rd }}$ days. Parameters measured: the state (condition) of flowers, diameter of flowers, vase life and the SPAD value of leaves.

To describe the change of the ornamental value of the flowers we created a scale with five degrees: $5=$ totally intact flower, 4 = beginning, palpable withering, $3=$ visible withering, 2 = intense withering, 1 = flower died away. As regards vase life, the flowers were considered as to be valueless (ripe for throwing out), when they reached the $3^{\text {rd }}$ grade.

We also elaborated a new method for the exact characterization of the ornamental value, that includes all the examined parameters (features). In the case of the different treatments we ranked the means of the examined parameters from 1-through 14. The parameters considered were as follows: chlorophyll content $(\mathrm{CH})$, diameter of flowers (DF) state of the flowers (SF), vase life (VL). The ornamental value (OV) was calculated with the next formula and was expressed in points:

$$
\mathrm{OV}=1 \times \mathrm{CH}+2 \times \mathrm{DF}+3 \times \mathrm{SF}+4 \times \mathrm{VL}
$$

The treatments are summarized in Table 1.

The chlorophyll measurements were carried out with a Konica Minolta SPAD-chlorophyll meter, 502 type. The chlorophyll content of the calyx was measured. The photographs were taken with a digital camera Panasonic Lumix FZ-8. The diameter of flowers also was measured.

\section{RESULTS}

\section{SPAD (chlorophyll) values}

Using a Konica SPAD-chlorophyll meter we succeeded in revealing differences among the treatments. Remarkably, at the time of the last evaluation, the leaves of flowers turned yellow, in both Clorox, and Clorox $+10 \mathrm{gL}^{-1}$ sucrose containing solutions, whereas in all other solutions the leaves remained green. In average, the highest values $(54, \hat{4})$ were measured in the case of "Spring" application, on the $7^{\text {th }}$ day (Figures 1-2).

\section{Diameter of flowers}

The diameter of flowers is an important parameter from the viewpoint of ornamental value. In the control solution, the flowers hardly opened. A much better result was achieved, when $20 \mathrm{gL}^{-1}$ sucrose was added to Clorox (7,3 $\mathrm{cm}$ ), and also in the case of "Spring" + 1-MCP (18 hours) $(7,4 \mathrm{~cm})$. Similar values were recorded in the case of "Spring" (7,3 cm), Clorox $+20 \mathrm{gL}^{-1}$ sucrose with 1-MCP (6 and 18 hours) $(7,3 \mathrm{~cm})$. The longer MCP treatment gave superior results as compared to the shorter one, mainly due to the slight opening of flowers. (Fig. 3-4).

\section{State of flowers}

There was only an insignificant difference among the treatments, on the $3^{\text {rd }}$ day. On the $7^{\text {th }}$ day, however, already significant differences could be observed. In the 18 hour MCP treatments Clorox $+20 \mathrm{gL}^{-1}$ sucrose proved to be the best. A similar tendency was observed also in the case of "Spring" application. This similarity persisted also on the subsequent days. Outstanding results were recorded with the use of MCP, where even the longer treatments gave superior results. On the $10^{\text {th }}$ day, the condition (state) of the flowers was best, in the solution of Clorox $+20 \mathrm{gL}^{-1}$ sucrose $(3,0)$ and "Spring" solution combined with the longer MCP treatment $(3,4)$, and Clorox $+20 \mathrm{gL}^{-1}(3,0)$. Mediocre results were recorded in the case of both Clorox $+10 \mathrm{gL}^{-1}+1$-MCP $(6$ and 18 hour $)$ treatment and in the control solution (Fig. 5-8).

\section{Vase-life of the flowers}

The longest vase life (10,3 day) was achieved in the case of "Spring" application combined with the 18 hour MCP treatment. This was followed by the Clorox $+20 \mathrm{gL}^{-1}$ sucrose +18 hours $1-\mathrm{MCP}$ treatment variant. Shorter vase life $(6,0$ day) was observed as a result of Clorox application combined with the $10 \mathrm{gL}^{-1}$ sucrose +6 hours $1-\mathrm{MCP}$ treatment. In the control solution the vase life proved to be 7,0 days. (Table 1).

Table 1. Treatments of the experiment, the vase life and the ornamental value of the flowers

\begin{tabular}{|l|c|c|}
\hline TREATMENTS & $\begin{array}{c}\text { Vase life } \\
\text { (day) }\end{array}$ & $\begin{array}{c}\text { Ornamental } \\
\text { value }\end{array}$ \\
\hline 1. Distilled water & $7,0 \mathrm{de}$ & 53 \\
\hline 2A. Distilled water $+1-M C P(6 h)$ & $6,4 \mathrm{de}$ & 29 \\
\hline 2B. Distilled water +1 -MCP $(18 h)$ & $8,4 \mathrm{bc}$ & 65 \\
\hline 3. Clorox & $8,4 \mathrm{bc}$ & 60 \\
\hline 4A. Clorox $+1-M C P(6 h)$ & $7,7 \mathrm{~cd}$ & 48 \\
\hline 4B. Clorox $+1-M C P(18 h)$ & $9,0 \mathrm{abc}$ & 76 \\
\hline 5A. Clorox $+10 \mathrm{~g}$ sucrose $+1-M C P(6 h)$ & $6,0 \mathrm{e}$ & 12 \\
\hline 5B. Clorox $+10 \mathrm{~g}$ sucrose $+1-M C P(18 h)$ & $6,4 \mathrm{e}$ & 27 \\
\hline 6. Clorox $+20 \mathrm{~g}$ sucrose & $9,5 \mathrm{ab}$ & 119 \\
\hline 7A. Clorox $+20 \mathrm{~g}$ sucrose $+1-M C P(6 h)$ & $8,9 \mathrm{abc}$ & 91 \\
\hline 7B. Clorox $+20 \mathrm{~g}$ sucrose $+1-M C P(18 h)$ & $9,9 \mathrm{a}$ & 129 \\
\hline 8. Spring & $9,1 \mathrm{abc}$ & 108 \\
\hline 9A. Spring $+1-M C P(6 h)$ & $9,0 \mathrm{abc}$ & 99 \\
\hline 9B. Spring $+1-M C P(18 h)$ & $10,3 \mathrm{a}$ & 134 \\
\hline
\end{tabular}

Means followed by different letters differ significantly for each other according to Duncan multiple range test at $\mathrm{P}=0.05$. 


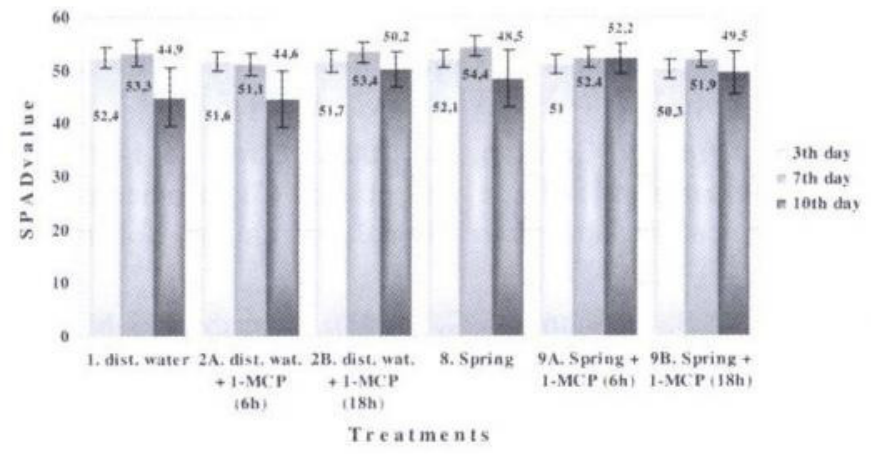

Fig. 1. The effect of chemical treatments on the chlorophyll content of flower leaves during the experiment

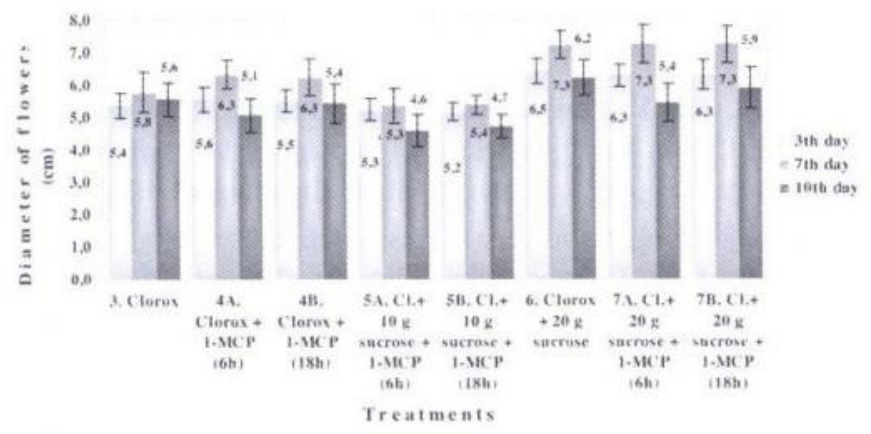

Fig. 3. The effect of chemical treatments on the flower diameter during the shelf life

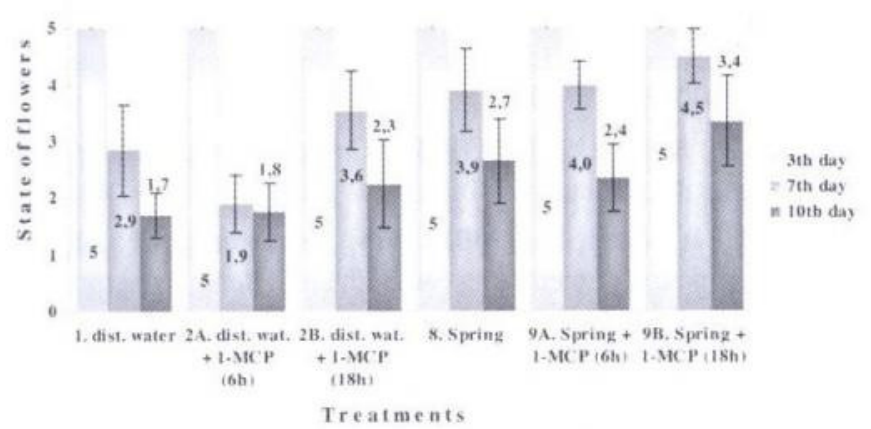

Fig. 5. The effect of chemical treatments on state of flowers during the experiment

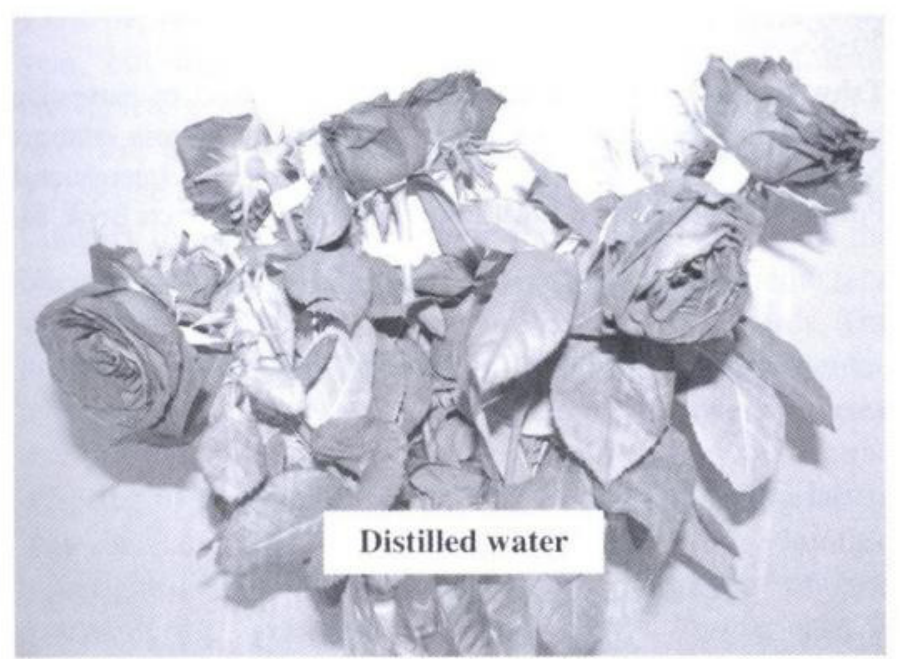

Fig. 7. The picture of the flowers in the control solution after the 10 days

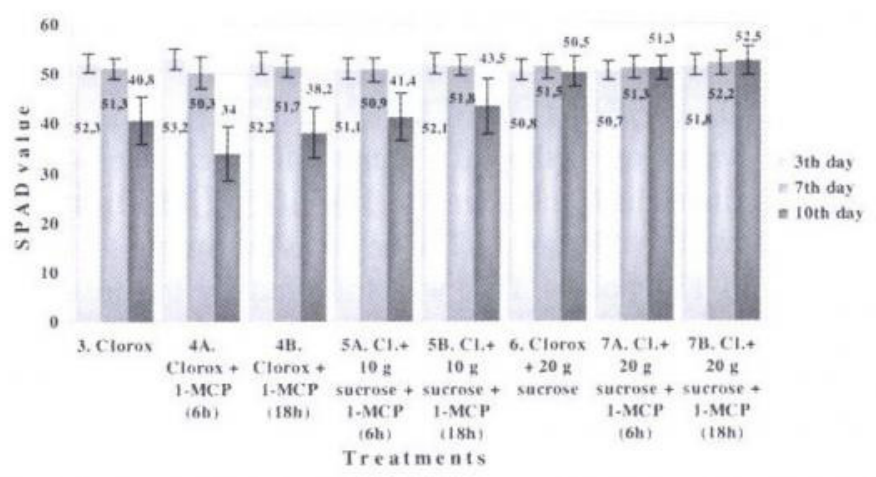

Fig. 2. The effect of chemical treatments on the chlorophyll content of flower leaves during the experiment

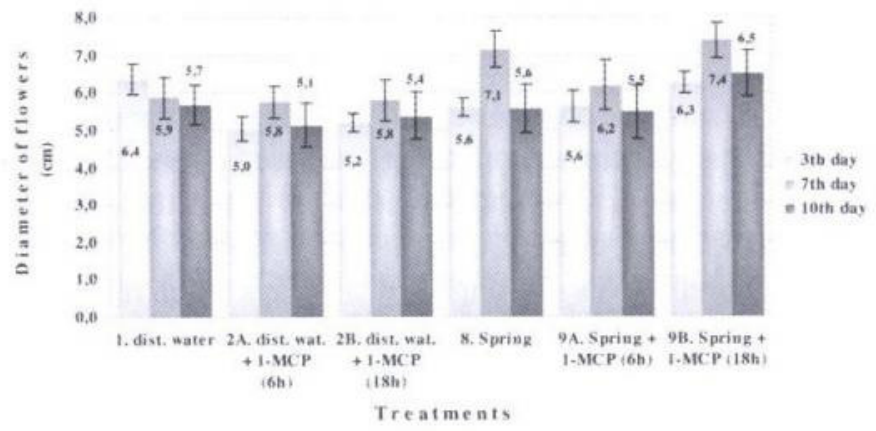

Fig. 4. The effect of chemical treatments on the flower diameter during the shelf life

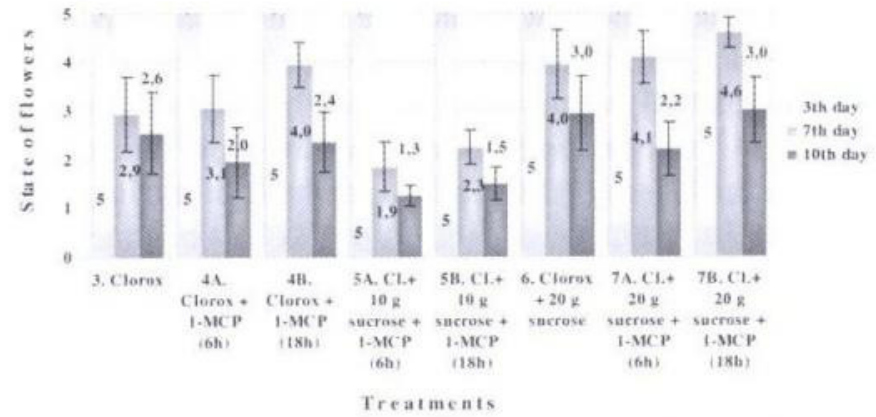

Fig. 6. The effect of chemical treatments on state of flowers during the experiment

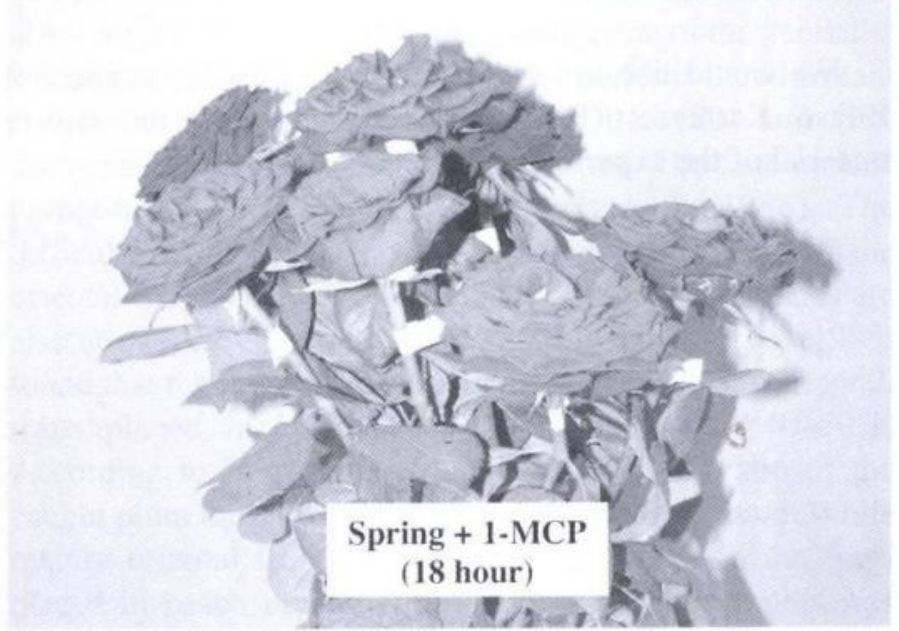

Fig. 8. The picture of the flowers in the Spring $+1-\mathrm{MCP}(18$ hour) treatment after the 10 days 


\section{Ornamental value}

The calculated data are summarized in Table 1. By using our new evaluation method, the minor differences can be both better distinguished and identified. The four best treatment gained more than 100 points. The best was the Spring $+1-\mathrm{MCP}$ (18h) with 134 points. This was followed by the treatment Clorox $+20 \mathrm{gL}^{-1}$ sucrose +1 -MCP (18h) with 129 points, and the variant Clorox $+20 \mathrm{gL}^{-1}$ sucrose with 119 points.

\section{Discussion}

It can be concluded, that in terms of both vase life and the ornamental value of flowers, the 18 hour long MCP treatments proved to be superior to the 6 hour long MCP treatments and the control. Our results are in harmony with the findings by Cuquel et al. (2007). These observations also verify our previous results with the imported cultivar 'Bordeaux' (Terék et al, 2009).

The vase life was prolonged by 3,3 days when the Spring and the 18 hours MCP treatment were applied jointly. It could be concluded that 1-MCP, in combination with "Spring" and sucrose, exerted a positive effect in both increasing the vase life and improving the postharvest quality of the cut flowers of rose cultivar 'Bordeaux'.

The ornamental value is a very important trait of roses. It is mainly determined by the opening of the flowers, the vase life, the state of the flowers and the colour of the leaves. We elaborated a new method that makes it possible to calculate the ornamental value with precision. Using this, we succeeded in separating even such minor differences that were not revealed by the standard methods of mathematical statistics. In summary, as a result of the best treatment, i.e. the joint application of "Spring" + 1-MCP (18hrs), the flowers stayed open preserving their ornamental value for longer periods and this was accompanied by the leaves maintaining their green colour.

\section{Acknowledgement}

We would like to express our thanks for the support of Bozsó Kertészet (Balástya), for supplying the flower material of the experiments.

\section{References}

Cuquel, F.L., Drefahl A. \& Dronk G.A. (2007): Enhancing vase life of rose with 1-MCP. Acta Hort., 751: 455-458.

Hassan, F.A.S. \& Gerzson, L. (2002): Effect of 1-MCP (1methylcyclopropene) on the vase life of Chrysanthemum and Carnation cut flowers. International Journal of Horticultural Science, 8 (3-4): 29-32.

Hassan, F.A.S. \& Schmidt, G. (2003): Efficacy of 1-MCP (1methylcyclopropene) for extending the vase life of some cut flowers comparing with other chemicals. The fourth international conference of Ph.D students. University of Miskolc, Hungary. 11-17 August., 73-78.

Hassan, F., Schmidt, G., Hafez, Y.M., Miklos, P. \& Ankush, J. (2004): 1-MCP and STS as ethylene inhibitors for prolonging the vase life of carnation and rose cut flowers. International Journal of Horticultural Science, 10 (4): 101-107.

Ichimura, K., Y. Kawabata, M. Kishimoto, R. Goto \& K. Yamada. (2002) Variation with the cultivar in the vase life of cut rose flowers. Bulletin of the National Institute of Floricultural Science, 2: 9-20.

Mayak, S., A. H. Halevy, S. Sagie, A. Bar-Yoseph \& B. Bravdo. (1974) The water balance of cut rose flowers. Physiol. Plant., 31: $15-22$.

Nell, T.A. \& R.T. Leonard. (2005) The effect of storage temperatures on colombian grown cut rose varieties. Acta Hort., 669: $337-342$.

Pizano, M. (2009) Research shows the way for post-harvest treatment roses. Flower Tech., 12 (6): 11-13.

Sisler, E.C. \& Serek, M. (1997): Inhibitors of ethylene responses in plants at the receptor level: recent developments. Physiologia plantarum, 100 (3): 577-582.

Sisler, E.C. \& Serek, M. (1999): Compounds controlling the ethylene receptor. Botanical Bulletin of Academia Sinica, 40: 1-7.

Sisler, E.C. \& Serek, M. (2001): New developments of ethylene control compounds interacting with the ethylene receptor. Acta Horticulturae. 543: 33-37.

Terék, O., Jámborné, Benczúr, E. \& Máthé, Á. (2009.): Tartósitóoldatok hatása a 'Bordeaux' rózsafajta diszitő értékére és tartósságára Kertgazdaság, 41 (1): 29-35.

Treerné, Windisch, M. \& Richter, K. (2008) Különböző tartósitószerek hatása két vörös rózsa vágófajtára. Kertgazdaság, 40 (3): $56-65$.

Tshwenyane, S. \& Bishop, C. (2009): The effect of harvesting time on the respiration and vase life of three cut rose cultivars 'Golden Gate', 'Duett', and 'Cream Prophyta'. $6^{\text {th }}$ International Postharvest Symposium. 08-12. April, Antalya. Abstracts Book, 84. 